\title{
Kandungan Antioksidan Pada Daun Kelor (Moringa Oleifera) dan Potensi Sebagai Penurun Kadar Kolesterol Darah
}

\author{
Angelyn Tjong, ${ }^{1}$ Youla A. Assa, ${ }^{2}$ Diana S. Purwanto ${ }^{3}$
}

\author{
${ }^{1}$ Program Studi Pendidikan Dokter Fakultas Kedokteran Universitas Sam Ratulangi \\ Manado, Indonesia \\ ${ }^{2}$ Bagian Biokimia Fakultas Kedokteran Universitas Sam Ratulangi Manado, Indonesia \\ Email: tjongangelyn99@gmail.com
}

\begin{abstract}
One of the biggest risk factors for cardiovascular disease is hypercholesterolemia. Cholesterol is an important fat, however if it is excessive in the blood it can cause various diseases, one of which is cardiovascular disease. One of the traditional medicines used to reduce blood cholesterol levels is Moringa Oleifera leaves, which contain flavonoids and play an important role in lowering blood cholesterol levels. This study aimed to determine the antioxidant content of Moringa Oleifera leaves, the benefits of lowering blood cholesterol levels, and the dosage of administration. This study was conducted by using three databases, namely PubMed, ClinicalKey and Google Scholar to find articles which met the inclusion and exclusion criteria, then the assessment was carried out. There was a significant reduction in blood cholesterol levels when given Moringa leaves, as well as the dose given. In conclusion, antioxidants in Moringa leaves can reduce cholesterol levels in the blood.
\end{abstract}

Keywords: antioxidants, moringa leaves, cholesterol, cardiovascular

\begin{abstract}
Abstrak: Salah satu faktor risiko terbesar penyakit kardiovaskular adalah hiperkolesterolemia. Kolesterol merupakan lemak yang penting, namun jika berlebihan dalam darah dapat menyebabkan berbagai penyakit, salah satunya kardiovaskular. Salah satu obat tradisional yang digunakan untuk menurunkan kadar kolesterol darah adalah daun kelor (Moringa Oleifera), yang mengandung flavonoid dan berperan penting dalam menurunkan kadar kolesterol darah. Tujuan penelitian ini untuk mengetahui kandungan antioksidan daun kelor, manfaat sebagai penurun kadar kolesterol darah, dan dosis pemberian. Pencarian artikel menggunakan tiga database yaitu PubMed, ClinicalKey, dan Google Scholar untuk menemukan artikel sesuai dengan kriteria inklusi dan eksklusi, kemudian dilakukan penilaian. Terdapat penurunan kadar kolesterol darah yang signifikan ketika diberikan daun kelor dalam menurunkan kadar kolesterol darah, serta dosis yang diberikan. Sebagi simpulan, antioksidan pada daun kelor dapat menurunkan kadar kolesterol dalam darah.
\end{abstract}

Kata Kunci: antioksidan, daun kelor, kolesterol, kardiovaskular

\section{PENDAHULUAN}

Indonesia terdapat tanaman yang mengandung banyak manfaat bagi kesehatan masyarakat, namun tidak banyak orang yang mengetahui manfaat dari tanaman tersebut. Tanaman tersebut salah satunya yaitu daun kelor. Daun kelor (Moringa oleifera) adalah tanaman herbal yang banyak dijumpai di kalangan masyarakat khususnya didaerah tropis dan di Indonesia sudah tersebar luas. ${ }^{1}$ Kelor merupakan tanaman obat tradisional yang terbukti berkhasiat bagi masyarakat. Tanaman ini memiliki aktivitas antioksidan yang tinggi dengan kandungan zat aktif didalamnya yang bermanfaat bagi kesehatan. Senyawa aktif pada kelor banyak ditemukan pada bagian daunnya. ${ }^{2}$ Tanaman kelor mengandung gizi yang sangat tinggi. ${ }^{3}$ Salah satu masalah utama 
yang dihadapi oleh negara maju maupun berkembang termasuk Indonesia adalah penyakit kardiovaskuler.

Penyakit kardiovaskuler menempati peringkat utama penyebab kematian di dunia melebihi penyakit lain. Penyakit kardiovaskuler merupakan penyakit yang tidak menular yang paling sering menyebabkan kematian ${ }^{4}$. Penyakit jantung koroner merupakan salah satu yang menjadi permasalahan dalam dunia kesehatan. Penyakit jantung koroner merupakan kelainan pada satu atau lebih dimana terdapat penebalan dalam pembuluh darah disertai penumpukkan plak yang mengganggu laju aliran darah ke otot jantung yang mengakibatkan terganggunya fungsi kerja jantung. ${ }^{5}$

Berdasarkan data World Health Organization (WHO), lebih dari 17 juta orang meninggal akibat penyakit jantung koroner dan yang menempati urutan pertama dari sepuluh penyakit yang menyebabkan kematian. ${ }^{6}$

Menurut statistik dunia, ada 9,4 juta kematian setiap tahun yang disebabkan oleh penyakit kardiovaskuler dan $45 \%$ kematian tersebut disebabkan oleh penyakit jantung coroner. ${ }^{7}$ Data dari Riset Kesehatan Dasar Indonesia tahun 2018 menyatakan bahwa prevalensi penyakit jantung koroner berdasarkan diagnosis sebesar $1,5 \%$ dari 1.000 penduduk Indonesia. ${ }^{8}$ Tingginya angka kunjungan ke rumah sakit disebabkan karena adanya keluhan yang tidak disadari oleh penderita sehingga sangat penting bagi kita untuk mengenali faktor risiko apa saja yang meningkatkan risiko penyakit jantung koroner, salah satunya adalah kadar kolesterol darah.

Secara normal, kolesterol diproduksi oleh tubuh. Akan tetapi cenderung mengonsumsi makanan dengan lemak tinggi, menyebabkan kolesterol berada dalam jumlah berlebihan dalam darah. Akibat gaya hidup dan mengonsumsi makanan yang tidak sehat serta kurangnya beraktivitas dan sering mengonsumsi makanan yang tinggi lemak.

Kadar kolesterol yang abnormal akan meningkatkan risiko pembentukan plak aterosklerosis di pembuluh darah mikro. Kolesterol secara sederhana merupakan komponen lemak dalam darah yang terdiri dari HDL (High Density Lipoprotein) dan LDL (Low Density Lipoprotein). Jika terjadi jejas pembuluh darah maka komponen LDL dapat lewat di saluran pembuluh darah dan dapat masuk ke dalam subendotel, menyebabkan lipid yang masuk akan teroksidasi dan terbentuk foam cell. ${ }^{9}$

Ada tahapan awal pengobatan penurunan kolesterol, tahap 1 terapi non farmakologis yaitu diet dan sering berolahraga, jika terapi non farmakologis gagal lanjut pada tahapan 2 terapi farmakologis dengan menggunakan obat alami atau obat moderen. ${ }^{2}$ Peningkatan kadar kolesterol umumnya tidak menimbulkan gejala awal, sehingga pemeriksa melakukan pemeriksaan sebagai tindakan pencegahan. ${ }^{10}$ Pada saat ini banyak beredar obat penurun kolesterol atau obat antikolesterol yang banyak dijual dipasaran. Dalam hal ini peneliti melakukan penelitian berdasarkan literature review tentang daun kelor (moringa oleifera) potensi sebagai penurun kolesterol.

\section{METODE PENELITIAN}

Penelitian ini berbentuk literature review yang dilakukan dengan mengidentifikasi, mengevaluasi, serta menginterpretasi semua hasil penelitian terkait topik tertentu atau fenomena yang menjadi fokus perhatian. Di samping itu literature review itu sendiri merupakan metode penelitian yang merangkum hasilhasil penelitian primer untuk penyajian fakta yang lebih komprehensif serta berimbang.

Pencarian literatur melalui publikasi di tiga database dan menggunakan kata kunci moringa oleifera AND cholesterol, moringa leaves AND cholesterol, moringa oleifera AND cardiovascular, daun kelor AND kolesterol. Hasil kemudian dipilih sesuai dengan tema bahasan dalam penulisan ini. Kemudian artikel hasil pencarian dirangkum dalam bentuk tabel. 


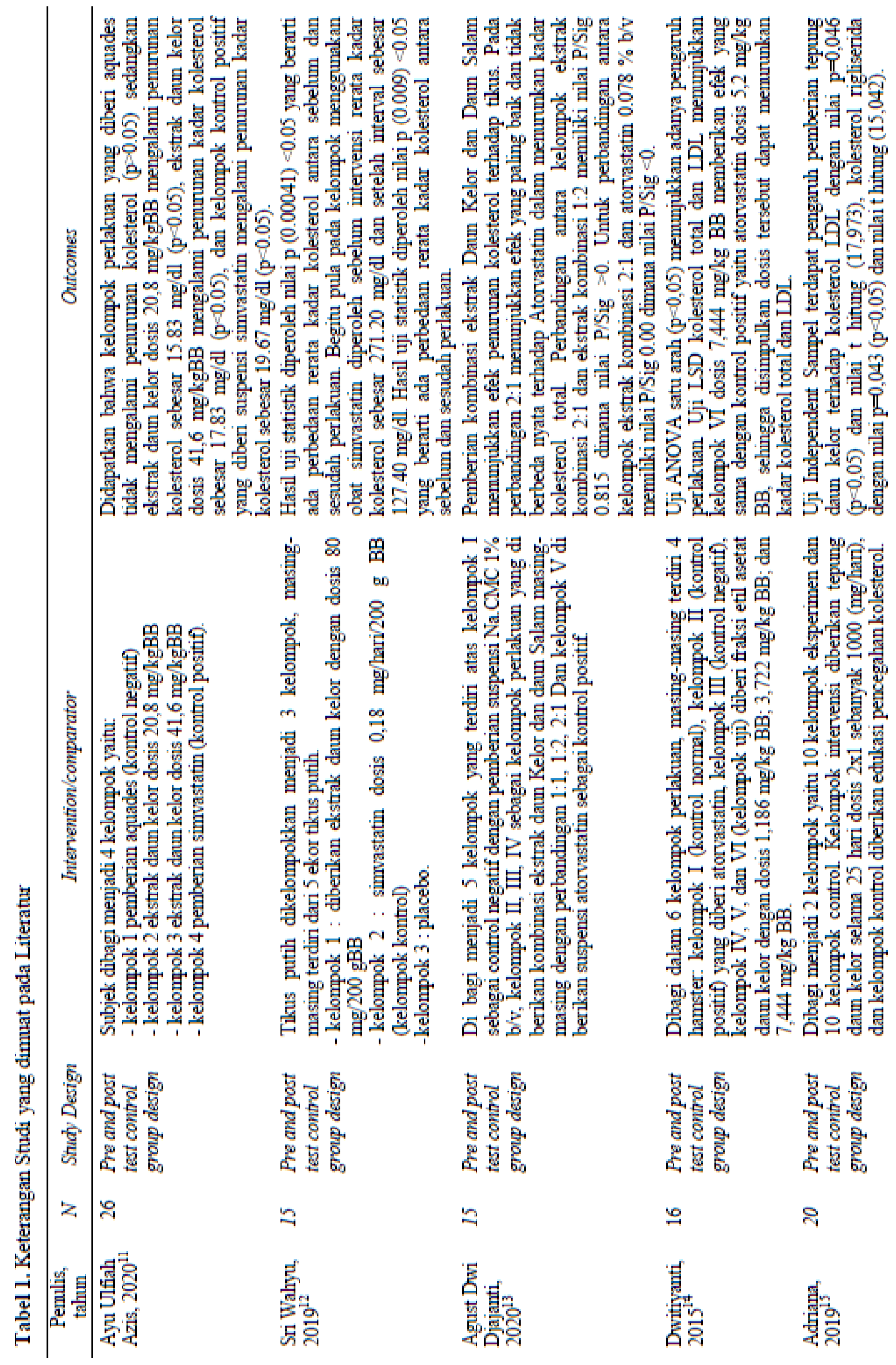



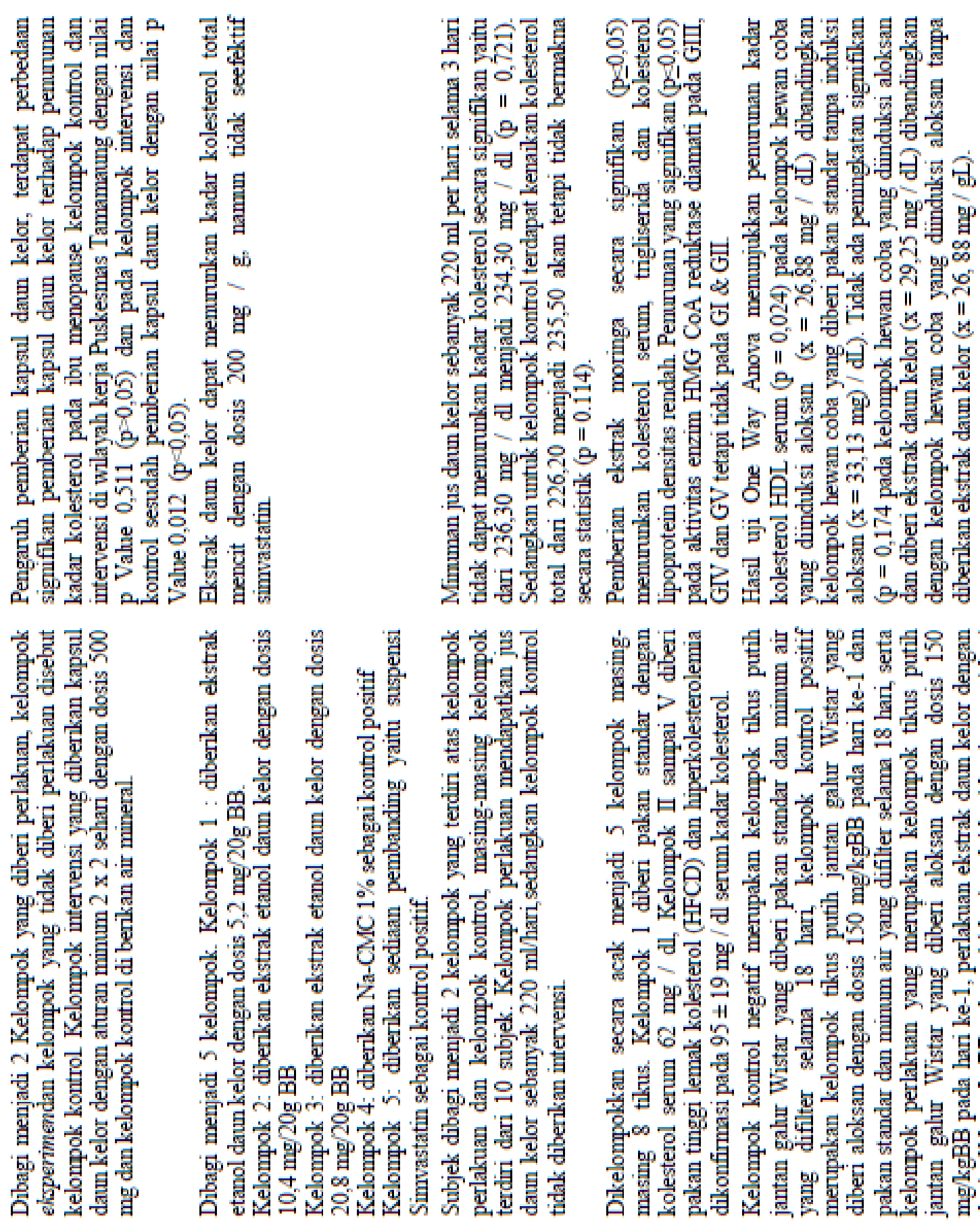

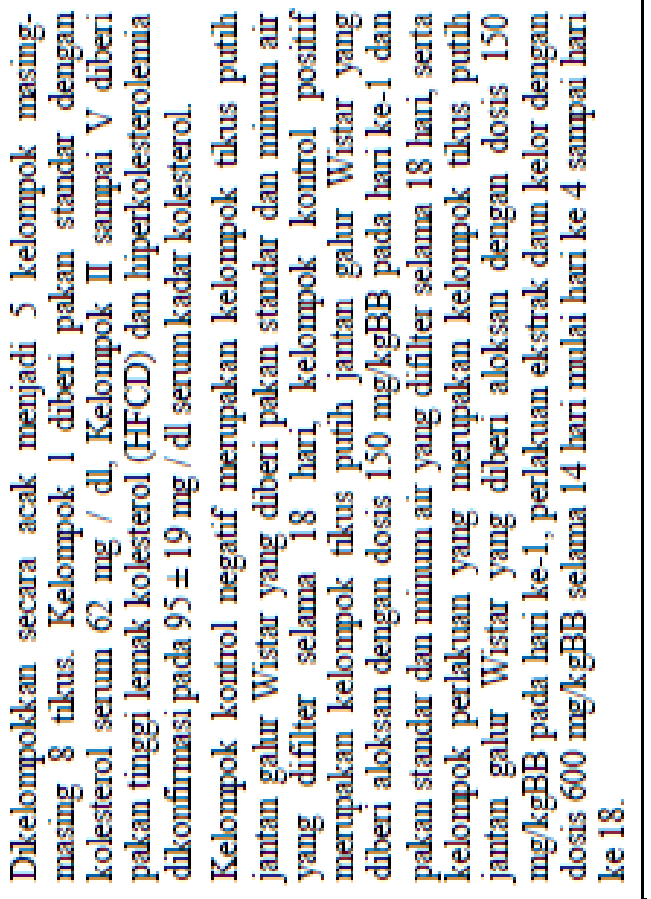

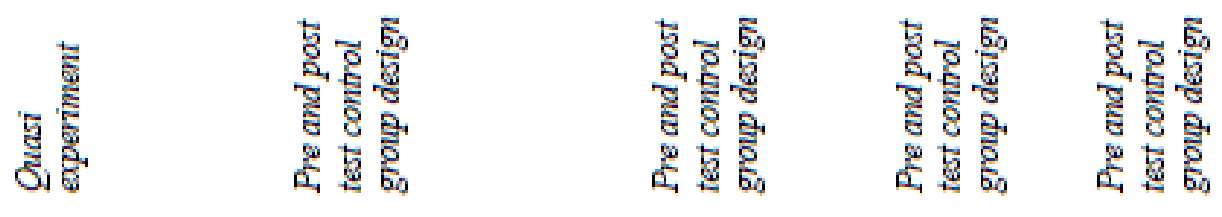

\begin{tabular}{|c|c|c|c|}
\hline 우 & $\stackrel{2}{2}$ & 요 & 우 \\
\hline 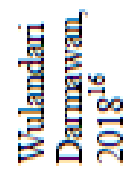 & 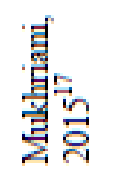 & 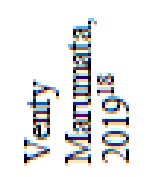 & 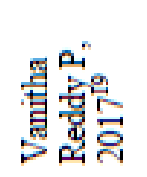 \\
\hline
\end{tabular}




\section{HASIL PENELITIAN}

Peneliti mendapatkan artikel sebanyak 8.059 Google scholar, 35 Pubmed, 14 Clinical Key yang sesuai dengan kata kunci dan dapat diakses fulltext dalam format pdf dan original. Hasil pencarian yang sudah didapatkan kemudian dilakukan skrining berdasarkan judul yang sesuai dengan tema literature review dan diperoleh 35 artikel. Selanjutnya dilakukan penilaian kelayakan untuk memilih sesuai dengan kriteria inklusi dan didapatkan 10 artikel jurnal ${ }^{11-20}$ untuk dilakukan penilaian (Tabel 1).

\section{BAHASAN}

Hasil penelitian secara umum menyebutkan bahwa Daun Kelor memang terbukti mampu menurunkan kadar kolesterol darah. Kandungan antioksidan diantaranya vitamin C, polyphenol, flavonoid dan karoten. Dimana vitamin C merupakan antioksidan alami yang memiliki aktivitas antioksidan yang paling tinggi dan yang berfungsi sebagai inhibitor untuk menghambat oksidasi dengan cara bereaksi dengan radikal bebas reaktif membentuk radikal bebas tak reaktif yang relatif stabil.

Kandungan $\beta$-karoten pada ekstrak daun kelor juga melindungi membran lipid dari peroksidasi dan sekaligus menghentikan reaksi rantai dari radikal bebas. Ekstrak daun kelor juga mengandung beta sitosterol yang menurunkan kadar kolesterol dengan cara menurunkan konsentrasi LDL dalam plasma dan menghambat reabsorbsi kolesterol dari sumber endogen. Kandungan flavonoids dan polyphenols secara signifikan dapat meningkatkan Superoxide Dismutase (SOD) dan katalase serta menurunkan kadar lipid peroksidase sehingga dapat menurunkan kadar kolesterol. ${ }^{1,21}$

Dosis yang ditampilkan oleh berbagai penelitian menunjukkan angka yang bervariasi serta menggunakan kontrol yang juga bervariasi. Dosis terendah yang menunjukkan hasil efektif adalah 0,2 $\mathrm{mg} / \mathrm{kgBB}$. Penelitian tersebut juga melaporkan bahwa meskipun efektif untuk menurunkan kadar kolesterol, dosis tersebut tidak seefektif simvastatin, hal ini didukung dengan tidak adanya nilai statistik yang dicantumkan. ${ }^{17}$ Sedangkan yang lain melaporkan dosis yang lebih tinggi, yaitu $7,44 \mathrm{mg} / \mathrm{kgBB}$. Dosis tersebut dilaporkan efektif untuk menurunkan kadar kolesterol darah serta memiliki efektivitas yang sama baiknya dengan atorvastatin. ${ }^{14}$ Penelitian lain yang menggunakan dosis lebih tinggi melaporkan bahwa dosis ekstrak daun kelor yang efektf untuk menurunkan kadar kolesterol darah adalah 20,8 dan $41,6 \mathrm{mg} / \mathrm{kgBB}$. Penelitian tersebut juga menyatakan bahwa dosis yang memiliki efektivitas sama dengan simvastatin adalah dosis $41,6 \mathrm{mg} / \mathrm{kgBB} .^{11}$

Namun ada juga penelitian yang melaporkan bahwa tidak ada perbedaan yang signifikan antara pemberian ekstrak daun kelor dan pemberian obat simvastatin dalam menurunkan kadar kolesterol darah. ${ }^{12}$ Selain itu, ada juga penelitian yang dilakukan sedikit memodifikasi bahan cobanya. Penelitian tersebut menggunakan kombinasi daun kelor dan daun salam untuk menurunkan kadar kolesterol darah. Hasilnya, penelitian tersebut melaporkan bahwa kombinasi daun kelor dan daun salam dengan perbandingan 2:1 memiliki efektivitas yang sama baiknnya dengan atorvastatin untuk menurunkan kolesterol darah. ${ }^{13}$ Juga ada penelitian lain yang melaporkan tambahan manfaat daun kelor. Penelitian tersebut mendapatkan bahwa ekstrak daun kelor tidak hanya efektif untuk menurunkan kadar kolesterol total, tetapi juga efektif untuk menurunkan kadar trigliserida dan kolesterol LDL. ${ }^{19}$

Namun terdapat perbedaan hasil dengan laporan dari Marumati (2019) yang menggunakan subjek penelitian manusia. Penelitian tersebut mendapati bahwa pemberian daun kelor tidak efektif untuk menurunkan kadar kolesterol darah. Ketidakefektifan ini diduga karena adanya perbedaan dalam sediaan yang digunakan. Penelitian ini juga menggunakan sediaan jus sebanyak $220 \mathrm{~mL}$, tanpa adanya variasi dosis berdasarkan berat badan. Selain itu, pemberian jus hanya selama tiga hari. Diduga tidak tepatnya dosis untuk setiap orang ditambah dengan terlalu singkatnya 
durasi hasil penelitian tersebut, sehingga menunjukkan hasil yang tidak efektif. ${ }^{18}$

Artikel ini masih sangat terbatas, namun setidaknya sudah cukup menampilkan artikel dengan penelitian yang sudah dipublikasi. Walau demikian masih dibutuhkan penelitian lanjutan dengan sampel pada manusia untuk membuktikan efektifitas kandungan kelor terhadap penurunan kolesterol darah. Kondisi ini didukung dengan kelebihan dari daun kelor yaitu, mudah didapat dan efek sampingnya sedikit bila diberikan pada manusia.

\section{SIMPULAN}

Pada daun kelor terdapat kandungan antioksidan seperti vitamin C, polyphenol, $\beta$-sitosterol dan flavonoid yang bermanfaat menurunkan kadar kolesterol dengan menurunkan konsentrasi LDL dalam plasma dan menghambat reabsorbsi kolesterol dari sumber endogen serta menurunkan kadar lipid peroksidase. Dosis yang efektif untuk menurunkan kadar kolesterol darah pada mencit adalah 0,2 $41.6 \mathrm{mg} / \mathrm{kgBB}$, cara pemberiannya dengan oral atau meminumnya. Penelitian ini belum banyak dilakukan pada manusia yang membahas tentang pemberian daun kelor dalam menurunkan kadar kolesterol darah manusia.

\section{Konflik Kepentingan}

Penulis menyatakan tidak terdapat konflik kepentingan dalam studi ini.

\section{DAFTAR PUSTAKA}

1. Amin MA. Pengaruh Bauran Pemasaran Jasa Terhadap Minat Kembali Pasien Non Asuransi Di Poli Rawat Jalan Rumah Sakit Umum Daerah Daya Kota Makassar. Jurnal Mitrasehat 2018;8(2):47988.

2. Salim R, Eliyarti E. Aktivitas Antioksidan Infusa Daun Kelor (Moringa Oleifera Lam.) Terhadap Warna Daun. Jurnal Katalisator 2019 31;4(2):91-102.
3. Rahmawati PS, Adi AC. Daya Terima Dan Zat Gizi Permen Jeli Dengan Penambahan Bubuk Daun Kelor (Moringa Oleifera). Media Gizi Indonesia 2016;11(1):86-93.

4. Warganegara E, Nur NN. Faktor Risiko Perilaku Penyakit Tidak Menular. Jurnal Majority 2016;5(2):88-94.

5. Wihastuti TA, Andarini S, Heriansyah T. Patofisiologi Dasar Keperawatan Penyakit Jantung Koroner: Inflamasi Vaskular. Malang: Universitas Brawijaya Press, 2016. 6. Setyaningrum N, Rejecky A. Pengaruh Pelatihan Bantuan Hidup Dasar Terhadap Motivasi Untuk Memberikan Pertolongan Pada Korban Henti Jantung Oleh Mahasiswa Pramugari. Surya Medika: Jurnal Ilmiah Ilmu Keperawatan dan Ilmu Kesehatan Masyarakat 2020;15(2):9-13.

7. Ghani L, Susilawati MD, Novriani H. Faktor Risiko Dominan Penyakit Jantung Koroner di Indonesia. Buletin Penelitian Kesehatan 2016;44(3):153-64.

8. Mutiarasari D. Ischemic stroke: symptoms, risk factors, and prevention. Medika Tadulako: Jurnal Ilmiah Kedokteran Fakultas Kedokteran dan Ilmu Kesehatan 2019;6(1):60-73.

9. Singh R, Kishore L, Kaur N. Diabetic Peripheral Neuropathy: Current Perspective And Future Directions. Pharmacological Research 2014;80:21-35.

10. Fairudz A. Pengaruh Serat Pangan Terhadap Kadar Kolesterol Penderita Overweight. Jurnal Majority 2015;4(8):121-6.

11. Ulfiah A, Arifin AF, Pratiwi R, Gayatri SW, Nurmadilla N. Efektifitas Pemberian Ekstrak Daun Kelor Terhadap Kadar Kolesterol Darah Pada Hewan Coba Mencit. UMI Medical Journal 2020;5(1):28-37.

12. Sri Wahyu, Andi SFA, Indah CM. Efektivitas Ekstrak Daun Kelor ( Moringa Oleifera) Terhadap 
Penurunan Kadar Kolesterol Total Pada Tikus Putih ( Rattus Novergicus). Green Med J 2019;1(1):97-110.

13. Djajanti AD, Firmansyah F, Basri I. Pengaruh Pemberian Kombinasi Ekstrak Daun Kelor (Moringa Oleifera Lam) Dan Ekstrak Daun Salam (Syzygium Polyanthum (Wight) Walp) Terhadap Penurunan Kadar Kolesterol Total Darah Pada Tikus Putih (Rattus Norvegicus). Fito Medicine: Journal Pharmacy and Sciences 2020;12(1):14-25.

14. Dwitiyanti D, Sunaryo H, Kania IR. Uji Aktivitas Antihiperkolesterolemia Fraksi Etil Asetat Ekstrak Daun Kelor (Moringa Oleifera Lam.) Terhadap Kadar Kolesterol Total Dan Ldl Kolesterol Pada Hamster Hiperkolesterolemia. Pharmacy: Jurnal Farmasi Indonesia 2015; 12(2):153-63

15. Adriana V, Alwi MK, Syam A. Pengaruh Pemberian Tepung Daun Kelor (Moringa Oleifera) Terhadap Propil Lipid Pada Penderita Pradiabetes Di Wilayah Kerja Puskesmas Samata Kab. Gowa. Jurnal Ilmiah Kesehatan Diagnosis 2019;13(6):622-32.

16. Darmawan W, Kurnaesih E, Multazam A. Pengaruh Pemberian Kapsul Daun Kelor Terhadap Penurunan
Kadar Kolesterol Pada Ibu Menopause Di Wilayah Kerja Puskesmas Tamamaung. Jurnal Mitrasehat 2018;8(2):381-8.

17. Mukriani M, Nurlina N, Nilan A, Rauf A. Uji Efektivitas Ekstrak Daun Kelor (Moringa Oleifera L) Terhadap Penurunan Kadar Kolesterol Darah Pada Mencit (Mus Musculus) Jantan. Jurnal Farmasi 2014;2(3):115-20.

18. Marumata CV, Woda RR, Artawan IM. Pengaruh Pemberian Jus Daun Kelor (Moringa Oleifera Lam) Terhadap Kadar Kolesterol Total Orang Dewasa Hiperkolesterolemia Di Wilayah Kerja Puskesmas Oebobo Kota Kupang. Cendana Medical Journal 2019;7(2):325-34.

19. Reddy V, Urooj A, Sairam S, Ahmed F, Prasad NN. Hypocholesterolemic Effect Of Moringa Oleifera Polyphenols In Rats Fed High FatCholesterol Diet. Malaysian Journal Of Nutrition 2017;23(3): 473-8.

20. Satrianawaty LD, Sumarno TM, Prabowo S. Hang Tuah Medical Journal. Hang Tuah Med J. 2019;17(1):35-46.

21. Isnan W, Muin N. Ragam Manfaat Tanaman Kelor (Moringa Oleifera Lamk.) Bagi Masyarakat. Buletin Eboni 2017;14(1):63-75. 